\title{
INCREASING PARTICIPATION OF SUB- SAHARAN AFRICAN ENTREPRENEURS IN CAPITAL MARKETS - A STUDY OF GHANA
}

\author{
[Anthony Q. Q. Aboagye]
}

Abstract - Well-functioning stock exchanges have been linked to economic growth in many parts of the world. However, in sub-Saharan Africa (SSA) listed companies and stock exchange activities reflect very little of country economic activities and economic output remains low. Research that has focused on unravelling constraints hampering the development of stock exchanges has been mostly aimed at identifying and removing transactional bottlenecks - trading systems, liquidity, institutions, and market integration. This study, conceived of as a fore-runner of the study of other SSA economies, identifies a new perspective on how to strategize for more companies in SSA to access the capital markets. Responses from World Values Survey type questionnaire were analyzed. Regression results suggest that variables that explain the proportion of own businesses that respondents will sell to the public to access capital markets relate to the values of the people, (trust), and the business environment. We propose a SSA wide study for a deeper understand of the issues.

Keywords- Ghana; Africa; stock exchange listings; entrepreneurs; economic growth; logit regression; culture values; trust; socio economic expansion; business expansion; World Values Survey.

\section{Introduction}

Under the tutelage of Western financial institutions, many sub-Saharan African (SSA) countries have been reforming their economies for some time now. One prescription that has gained substantial traction is the promotion of stock exchanges in SSA. Today, one can count as many as 28 fledgling stock exchanges in SSA. However, to the casual observer, neither stock exchange activities nor economic output are impacting the lives of the people in any serious way.

To illustrate the point is Table 1, which is suggestive of the relationship between stock exchange activity and gross domestic products (GDP) of a number of economically advanced countries and for some SSA countries. It relates the values of stocks traded in these economies to GDP from 2008 to 2011. Without doubt, the SSA ratios (save South Africa) are miniscule, a far cry from their counterparts in the rest of the world, where capital markets are better developed. To relate these figures to economic well-being, the last column of Table 1 indicates per capita GDP. Without a doubt, SSA countries lag far behind here too, (save South Africa and Mauritius, both known to have well developed stock exchanges).

Anthony Q. Q. Aboagye

University of Ghana

Ghana
Table 1: African countries and rest of the world Capital markets and GDP

\begin{tabular}{|c|c|c|c|c|c|}
\hline \multirow[b]{2}{*}{ WORLD } & \multicolumn{4}{|c|}{$\begin{array}{c}\text { Total value of stocks traded as } \\
\% \text { of GDP } \\
\end{array}$} & \multirow{2}{*}{$\begin{array}{c}\text { GDP (PPP) per } \\
\text { capita (Current } \\
\text { USD) } \\
2011 \\
\end{array}$} \\
\hline & 2008 & 2009 & 2010 & 2011 & \\
\hline Germany & 85.7 & 39.1 & 42.8 & 48.8 & 39,456 \\
\hline Japan & 121.2 & 83.3 & 78 & 70.9 & 33,668 \\
\hline $\begin{array}{l}\text { South } \\
\text { Korea }\end{array}$ & 157.4 & 189.6 & 160.3 & 182.1 & 29,834 \\
\hline UK & 244.9 & 155.8 & 133.3 & 121.5 & 35,598 \\
\hline US & 450.2 & 336.3 & 211.2 & 205.1 & 48,112 \\
\hline China & 61.8 & 100.3 & 80.3 & 46.3 & 8,400 \\
\hline \multicolumn{6}{|l|}{ AFRICA } \\
\hline Ghana & 0.5 & 0.2 & 0.3 & 0.3 & 1,871 \\
\hline Kenya & 4.7 & 1.6 & 3.4 & 2.6 & 1,710 \\
\hline Mauritius & 4.2 & 3.7 & 3.7 & 4.6 & 14,420 \\
\hline Nigeria & 9.6 & 2.7 & 2.3 & 1.7 & 2,533 \\
\hline Uganda & 0.5 & 0.1 & 0.1 & 0.1 & 1,302 \\
\hline $\begin{array}{l}\text { South } \\
\text { Africa }\end{array}$ & 146.6 & 121 & 93.5 & 91.2 & 10,000 \\
\hline
\end{tabular}

Source: World Bank

Also true is the fact that the number of exchange listed firms in each SSA country is small (Cameroon: 2 listed firms; Malawi: 8, Tanzania: 17, Ghana: 34, Kenya: 50, etc.). Further, listed companies on many SSA stock exchanges reflect very little of economic activities that take place in these countries. We illustrate for Ghana the level of stock exchange activities relative to GDP in the three broad sectors of the economy - Agriculture, Industry and Services in Table 2. For each sector, the market capitalization of stock exchange listed companies in that sector is tiny relative to the GDP of the sector. For example, USD 9.2 million of market capitalization versus USD 8,183 million in GDP for the Agricultural sector in 2012, a tiny percentage of 0.11 per cent.

Access to capital is critical to growing any economy. It is well documented that in most parts of Africa, business owners rely on family and friends to provide them with capital. Such approach is fraught with many problems high transaction costs; relatively small amounts of funds changing hands; substantially reduced avenues for diversifying risk, and inefficiencies in allocating capital. Formal capital markets have evolved to address these constraints. 
Table 2: Nominal GDP per sector of the Ghanaian economy in millions of United States dollars, 2010-2012.

\begin{tabular}{|c|c|c|c|c|c|}
\hline SECTOR & $\begin{array}{c}\text { GDP- } \\
\mathbf{2 0 1 0}\end{array}$ & $\begin{array}{c}\text { GDP- } \\
\mathbf{2 0 1 1}\end{array}$ & $\begin{array}{c}\text { GDP- } \\
\mathbf{2 0 1 2}\end{array}$ & $\begin{array}{c}\text { GSE- } \\
\mathbf{2 0 1 2}^{\mathbf{1}}\end{array}$ & $\begin{array}{c}\text { Ratio }^{2} \\
\mathbf{\%}^{\circ}\end{array}$ \\
\hline $\begin{array}{c}\text { AGRI- } \\
\text { CULTUR } \\
\text { E }\end{array}$ & 8,760 & 9,132 & 8,183 & 9.2 & $\mathbf{0 . 1 1 \%}$ \\
\hline $\begin{array}{c}\text { INDUSTR } \\
\text { Y }\end{array}$ & 5,628 & 9,230 & 9,785 & 3.1 & $\mathbf{0 . 0 3 \%}$ \\
\hline $\begin{array}{c}\text { SERVICE } \\
\text { S }\end{array}$ & 15,052 & 17,315 & 17,494 & 51.0 & $\mathbf{0 . 2 9 \%}$ \\
\hline
\end{tabular}

Source: GDP data from 2013 Budget Statement of Government of Ghana and GSE-2012 data from Ghana Stock Exchange Trading results. Exchange rates from Bank of Ghana.

${ }^{1}$ Market capitalization of listed firms per sector end of 2012

${ }^{2}$ Ratio of value of traded shares to GDP per sector in 2012.

Previous efforts aimed at increasing activity on SSA capital markets have focused on increasing liquidity and efficiency and reducing other transactional bottlenecks. For example, the Ghana Stock Exchange (GSE) has worked hard to reduce the maximum period within which transactions entered into on the floor of the exchange must be reflected in the books of listed firms to three days. For another, trading on the GSE has moved from 2 hours a day for three days of the week to 2 hours a day for five days of the week to current 5 hours a day for five days of the week. That is not all. Capital gains earned on GSE listed companies are tax-free. And for a long time, GSE listed companies were taxed at a preferential rate. And to avoid delays associated with paper security certificates and potential of loss, the GSE now operates a paperless securities depository.

Further, fees and commissions due to brokers, the Exchange and the Ghana Securities and Exchange Commission (SEC) have been made uniform. Then too, the GSE and the SEC have spent substantial amounts of resources and time trying to educate owners of companies about the advantages of listing on the GSE. In spite of all these, the number of listed companies and value of transactions have remained low.

In other parts of SSA, Hearn and Piesse (2010a) concluded that illiquidity, lack of truly dispersed ownership, poverty, wealth inequality, inadequate institutions and constraints to investments are barriers to the development of the stock markets in Swaziland and Mozambique. In two other papers, Hearn and Piesse (2010b) and Hearn (2014) state that size and liquidity explain stock returns in West African markets, and that returns to relatively more liquid stock markets are higher than in less liquid markets. Acquah (2015) has added that knowledge about stock market dynamics and financial institutions encourages listings on the GSE, while information and disclosure costs requirements, and loss of ownership and control discourage listings.

Other studies have called for integration of SSA stock exchanges, improving trading systems, better technical and institutional development, etc. These studies have also called for harmonization of legislations such as bankruptcy and accounting laws and liberalizing trade regimes. The studies include, Agyeman's (2010), Benimadhu (2003) and
Yartey and Adjasi (2007). These measures are aimed at increasing liquidity and efficiencies of transactions.

Under-development of emerging economy stock markets beyond SSA has also received attention. Identified factors include low patronage of these markets by investors due to lack of investor protection and inadequate transparency and information disclosure by firms. The studies include Billmeier and Massa, (2009); La Porta, Lopez-de-Silanes, Shleifer, and Vishny (1997, 1998, 2000). Prescriptions to address this shortcomings have focused on development of institutions and policies that will protect investors from expropriation.

It is the premise of this paper that to increase listing on the GSE and engender more activities, approaches that focus only on increasing liquidity and enhancing efficiency of trading on SSA exchanges (referred to as transactional constraints) by themselves will not solve the problem. To our mind, the constraints that entrepreneurs face when they contemplate listing go beyond these transactional issues. Relaxing these other constraints will involve addressing the softer issues of the people's values, the social and economic environment and people's attitudes and views about raising capital for business expansion.

We hypothesize that there is the need for a new perspective on how to strategize for more companies in SSA to access the capital markets. To this end, we suggest that cultural dimensions should be investigated. Evidence that culture plays an important role in explaining corporate decisions has been growing. One of Hofstede's (2001) four dimensions of culture is uncertainty avoidance. This reflects the extent to which people feel threatened by uncertain or unknown situations. It is possible that this is one of the factors holding back SSA entrepreneurs back. Adler (1997) has argued that culture influences people's values, attitudes and behavior.

This paper aims to obtain indication of the values, social and environmental issues, as well as business expansion and related issues that must be overcome in order for privately held firms in Ghana to access capital markets and get bigger. Vibrant capital markets provide systems for suppliers and users of long-term funds to transact business. We believe that the Ghanaian case provides a good case study of the African situation. What with a relatively young stock exchange, an economy that is performing reasonably well (over 5\% GDP growth over 20 years), liberalized economy (financial markets, trade, foreign exchange), etc.

The next section discusses finance and economic growth issues in the literature briefly. This is followed by a discussion of the conceptual framework of this study. We then present the methodology adopted for this study, then present and discuss our findings. We end with concluding remarks.

\section{Finance and Economic Growth and Culture}

\section{A. Finance and Economic Growth}

Economic theory emphasizes capital accumulation as a critical factor in economic progress. Capital 
accumulation enhances productivity and knowledge accumulation, infrastructure provision, etc. Schumpeter (1912) emphasized this, and has been re-emphasized by the likes of Goldsmith (1969) and McKinnon (1973). In the main, their argument is that an efficient financial sector helps mobilise savings for investment activities by firms to enhance production, leading to economic growth.

Under endogenous growth theory, the effects of financial markets can put an economy on a higher growth path permanently by enhancing savings, channeling investment funds to firms and improving the average productivity of capital. Also, stock markets provide services different to those provided by banks by making investments more liquid.

Empirical findings in support of positive relationship between economic output and the level of financial development are many. They date as far back as King and Levine (1993) and include El-Wassal (2005) and Uyanga and Suruga (2008) on emerging economies and Marashdeh and Al-Malkawi (2014) for Saudi Arabia. About Ghana.

A number of studies have cautioned against promotion of stock markets on grounds that such steps may lead to increased macroeconomic instability, undermine group banking system that has worked well in some markets, or even encourage counter-productive corporate takeovers. These researchers include Singh (1997) and Stiglitz (1994). Lucas (1988) suggested that increasing growth in the financial sector of small countries is unimportant in the context of economic growth. More important are inadequate social services, underdeveloped infrastructure, etc., he argued.

Aboagye (2005) studied 15 sub-Saharan Africa countries in the 1990s and found that stock market indicators were not having significant impact on output and suggested that this may be due to the poor macroeconomic environment.

\section{B. Culture and Economic Growth}

We have alluded to Hofstede (2001) and culture. In fact, Ghanaian culture, as is the case in many African countries, has been described by many researchers as highly collectivistic (e.g. Acquah, 2007). Meaning the extended family and broader community are important in defining values and behaviors in respect of property ownership (North, 1990). Acquah (2015) has argued many African businesses are small family owned and managed to maximize the utility of the family. Davis et al (1997) have argued that in societies with collective cultures, managers of family businesses have goal congruence with the rest of the family. Corbetta and Salvato, (2004, p. 356) argue that to perpetuate the family interest, the steward (manager on behalf of rest of family) may refuse to sell equity in the business publicly (for example, by not listing on a stock exchange).

The picture we have just painted may be better understood when one recalls that Acemoglu et al. (2004) develop the empirical and theoretical case that differences in economic institutions are the fundamental cause of differences in economic development. They added that economic institutions determine the incentives of, and the constraints on economic actors, and shape economic outcomes.

It is our hypothesis that factors such as those just discussed mitigate against small businesses in Ghana accessing capital markets in order to get bigger. To ground our hypothesis, we point to World Values Survey (WVS) by World Values Survey Association (2012), a project aimed at exploring globally people's values and beliefs and how these change over time. WVS has focused on measuring, monitoring and analyzing religion, trust in others, people's happiness, racial tolerance, etc. The WVS has established that people's beliefs are important in promoting economic development, among others. Findings over several waves of surveys since 1981 have established that there have been rapid changes in values and beliefs in economically advanced societies. On the other hand, very little changes have been noted in countries that have not made much progress economically. And that, in fact, there has been growing divergence in prevailing values in low-income countries and high-income countries.

Gorodnichenko and Roland (2011) present evidence that a number of cultural dimensions, based on Hofstede's data, are important for long term growth. Papamarcos and Watson (2006) found that cultural factors impact national economic performance. They caution that economic growth and the development of markets are influenced by cultures and that psychology, sociology, politics, law, etc. have roles to play in explaining economic performance.

This study provides evidence on the extent to which cultural factors affect, decisions by Ghanaian entrepreneurs to go public and sell outright (100\%) or proportions of firms they own.

\section{Methodology}

\section{A. Questionnaire and Sample}

To understand how values and beliefs of Ghanaians influence their attitudes towards participating in capital markets, we compiled a questionnaire that consisted of questions extracted from the values, social and economic environment sections of the World Values Survey (2012), and our own questions about business expansion and related issues. The WVS reports that its "findings are valuable for policy makers seeking to build civil society and democratic institutions in developing countries." And that their data are frequently used by "governments, international organizations and institutions such as the World Bank and the United Nations to better understand the world."

On values, our questionnaire asked whether respondents thought most people can be trusted and whether respondents thought others in general will deal fairly with them, or whether people would try to take advantage of them. On business expansion and related issues, we asked whether they would sell outright businesses they owned themselves or owned by their families. If they would not sell outright, the maximum proportion they would be willing to sell, and whether they would want their businesses to 
expand. We also asked about how they would raise money to expand, and what they thought of the attitude of Ghanaian workers to work. We closed by asking what they thought of i) the need to join forces with other co-owners of businesses for business expansion, and ii) the need to put in place proper corporate governance procedures. Similar questions were asked about the need to deal with government and state bureaucracies.

This questionnaire was then administered to 150 randomly selected second year Executive and Weekend graduate students of the University of Ghana Business School. These crop of students are aged 26 years and above (average age 32 years) and are in full time employment. $90 \%$ of them have worked for at least five years. Malefemale proportion is about 50\%-50\%.

70 copies of the questionnaire were returned in useable form, in May 2014 hence our analysis is based on this number. Our analysis of the survey response was in two parts. First, a summary of responses on individual questions is provided. This was followed by regressions to establish factors that are important to respondents in making capital market participation decisions.

\section{B. Regression Models}

\section{Factors that influence the decision to sell on capital markets}

We specified a logit model to explain their response to the question whether they would sell outright or not as the dependent variable, Y.

The logit relationship is given as

$$
P(Y=1 \mid X)=\frac{e^{b 0+b 1 X 1++b 2 X 2+\ldots .+b N X N}}{1+e^{b 0}+b 1 X 1++b 2 X 2+\ldots+b \text { wXN }}
$$

where, $\boldsymbol{P}$ is the probability of 1 , meaning will sell, $e$ is the base of natural logarithm and $\mathbf{b 0}, \mathbf{b} \mathbf{1}, \ldots \mathbf{b N}$, are parameters of the $\mathbf{N}$-dimensional explanatory matrix, $\mathbf{X}$, which is extracted from survey results.

\section{Factors that influence proportions that respondents are willing to sell to the public}

Next, we sought to understand those factors that are important in explaining the proportions of businesses respondents are willing to sell to the public. This is also a gauge of respondents' willingness to access external funds from investors who are not family or friends to expand their businesses. The minimum proportion a respondent can sell is nothing, $0 \%$, while the most any respondent can sell is everything, $100 \%$ and anything in between.

The version of OLS implemented is regression through the origin (no constant) because, i) the explanatory variables are all binary, including a constant as an explanatory variable increases the likelihood of ending up with a singular matrix; and ii) both the dependent and explanatory variables have values around the origin. The explanatory variables included indicators of values and trust in people and indicators of willingness to engage in business development and expansion.

\begin{abstract}
IV. Results
A Summary statistics Values and Trust

We started with the issue of trust and its likely influence on decisions to team up with others to access capital markets. 91.4 per cent of respondents declared that one needs to be very careful in dealing with others. 7.1 per cent said most people can be trusted. 32 per cent said they thought most people would try to take advantage of them. 39 per cent said most people would try to be fair. They remaining were unsure.
\end{abstract}

\section{Business expansion an related issues}

Only 17 per cent responded that they would consider selling outright businesses they started themselves at any stage of their life or of the life of the company. When the same question was put for a hypothetical family business, only 13 per cent said they would.

We followed up with a question about the maximum proportion of a hypothetical own business that they would sell to outsiders to raise money to expand business. We view responses to this question as indicating the extent to which respondents are willing to accept or work with other co-owners. The average proportion of own businesses that respondents would sell to raise capital is 39 per cent. Next, for those who would not sell outright a family business, the maximum proportion respondents would consider selling to raise capital averaged 33 per cent.

A follow up question asked respondents whether if they owned a business they would like it to grow and expand. Almost unanimously, respondents replied that they would. Our interest then moved to respondents' preferred avenues for raising funds for expansion. A number of options were provided. But these boiled down to two: raising funds by way of private sources, or avenues that amount to going public. Only 16 per cent indicated that they would prefer the public issue route. The others would go private.

On work ethics, we asked them whether they thought the average Ghanaian works hard. 44 per cent said yes. The rest said no. Next, we asked whether they thought Ghanaian workers would work hard if they were not being supervised closely a situation that could result if the business expanded). Only 23 per cent responded in the affirmative. Pushing the point further, we asked respondents whether if they were entrepreneurs, they would expand and hire more workers even if they could not supervise them closely because of the increased number of workers. 39 per cent said they would.

Then we turned to willingness to come together with others to enhance business and to deal openly and transparently with governmental bodies. The issues here border on the extent to which respondents are willing to take on co-owners and to abide by good corporate governance practices. For this, we asked whether a number of documented disincentives will impinge on their willingness to get together with others to run a business. Here are the responses: 
Proc. of the Third Intl. Conf. on Advances in Management, Economics and Social Science - MES 2015.

Copyright (C) Institute of Research Engineers and Doctors, USA .All rights reserved.

ISBN: 978-1-63248-081-1 doi: 10.15224/ 978-1-63248-081-1-37

\begin{tabular}{|c|c|}
\hline $\begin{array}{c}\text { Dimension of dealing with } \\
\text { government }\end{array}$ & $\begin{array}{c}\text { Percentage } \\
\text { responding YES }\end{array}$ \\
\hline $\begin{array}{c}\text { delayed decision making due to the } \\
\text { need to consult others }\end{array}$ & $33 \%$ \\
\hline $\begin{array}{c}\text { ultimate decision that is made being } \\
\text { a consensus decision }\end{array}$ & $20 \%$ \\
\hline $\begin{array}{c}\text { need to share profits if they owned } \\
\text { the business with others }\end{array}$ & $17 \%$ \\
\hline $\begin{array}{c}\text { need to deal with government } \\
\text { bureaucracy }\end{array}$ & $22 \%$ \\
\hline \multicolumn{2}{|c|}{$\mathbf{4 . 2}$} \\
\hline
\end{tabular}

\section{B. Estimation}

Two sets of regression models were estimated as indicated earlier. Explanatory variables are all indicator variables that take values 1 or 0 .

\section{Logit regressions - Will you sell outright?}

The first set of (logit) regressions model responses to the question whether respondents would sell outright companies they founded themselves (or family business) were estimated in Winrats 8.2. Estimates for both responses are practically identical. Here we report coefficients for $o w n$ business only. In exploratory general-to-specific modeling, one cultural variable and four business expansion and related issues proved highly correlated to the dependent variable and were retained for the regression.

Both models exhibit improvement in fit due to inclusion of the explanatory variables (over the base model of the intercept only). We judge these regressions to be adequate based on indicators of regression adequacy reported.

For both logit regressions, in Table 3, the intercept and two explanatory variables are significant. That is, pvalues are between 0.05 and 0 . The column Logit (1) of the table says that the odds that a respondent who answers no to all explanatory variables in the model will opt to sell outright a company he/she owned $100 \%$ is 0.13 to 1 . The predicted probability that such a respondent would sell is 11.6 per cent. This is small by most standards. The column Logit (2) of the table replaces the variable D10_V in (1) with D10_IV. This time the predicted probability that such a respondent will opt to go public is 7.5 per cent. Another small percentage.

\section{Explaining the proportions they will sell}

The findings of our OLS estimation to identify variables that explain the proportion of respondents own businesses that they would be willing to sell to others to obtain additional funds to expand business is given in Table 4. Four regressions were estimated. The differences arise from indicators of values and business expansion and related issues used as explanatory variables. The standard errors of the estimates are between 0.26 and 0.28 . Three of the uncentered R-squareds are 0.55 , the fourth is 0.60 . All four regressions have 96 degrees of freedom. We judged these regressions to be adequate.
Table 3: Explaining the probability that respondents will opt to sell outright

\begin{tabular}{|l|l|l|}
\hline Variable & LOGIT (1) $^{\mathrm{a}}$ & LOGIT (2) $^{\mathrm{a}}$ \\
\hline Intercept & $-2.03 * * *$ & -2.51 \\
& $(0.00)$ & $(0.00)$ \\
\hline D7 & -1.41 & -0.94 \\
& $(0.15)$ & $(0.32)$ \\
\hline D8 & 0.82 & 0.21 \\
& $(0.45)$ & $(0.83)$ \\
\hline D10_V & $1.36^{* *}$ & \\
& $(0.05)$ & \\
\hline D10_IV & & $1.96 * * *$ \\
& & $(0.01)$ \\
\hline A6 & $1.37 * *$ & $1.87 * * *$ \\
& $(0.05)$ & $(0.01)$ \\
\hline Log likelihood (base) & -33.39 & -33.60 \\
\hline $\begin{array}{l}\text { Log likelihood with } \\
\text { variables }\end{array}$ & -28.18 & -27.35 \\
\hline $\begin{array}{l}\text { LR Test of Coefficients } \\
\text { (4) }\end{array}$ & $10.41^{* *}$ & $\begin{array}{l}12.50 * * * \\
(0.03)\end{array}$ \\
\hline D. F. & 65 & 65 \\
\hline
\end{tabular}

Legend to variables:

\begin{tabular}{|l|l|}
\hline Variable & Definition \\
\hline D7 & $\begin{array}{l}\text { Does the average Ghanaian work hard. YES }= \\
1 ; \text { No }=0\end{array}$ \\
\hline D8 & $\begin{array}{l}\text { Do you think the average Ghanaian will work } \\
\text { hard if he/she is not being supervised closely? } \\
\text { YES }=1 ; \text { NO }=0 .\end{array}$ \\
\hline D10_IV & $\begin{array}{l}\text { Will having to deal with tax authorities and } \\
\text { other government bodies deter you from taking } \\
\text { on partners and co-workers? YES }=1 ; \text { NO =0. }\end{array}$ \\
\hline D10_V & $\begin{array}{l}\text { Will having to disclose profits }(\text { operating data) } \\
\text { to government bodies? YES }=1 ; \text { NO }=0 .\end{array}$ \\
\hline A6 & $\begin{array}{l}\text { Do you think most people would try to take } \\
\text { advantage of you if they got the chance, or } \\
\text { would they try to be fair? Would be FAIR }=1 ; \\
\text { Would take advantage }=0 .\end{array}$ \\
\hline
\end{tabular}

Three measures of willingness to come together with others to enhance business, deal openly and transparently with governmental bodies (good corporate governance practices) were used as explanatory variables, (D10_I, D10_III, and D10_IV). They are significant in the equations in which they appear. Two dimensions of values (zeroing on trust), A3 and A6 were included in the explanatory variables. Of these, A3 was not significant in its regression.

The regression results say that, the variable capturing respondents who think the average Ghanaian worker works hard (D7) is positive and significant in explaining the proportion they would be willing to sell in all four regressions. P-values vary from 0.02 to 0.0 . That is, respondents who think Ghanaian workers work hard would be willing to sell a significantly higher proportion (than those who think not) of their businesses to other co-owners for infusion of capital so that the business can get bigger. 
Table 4: Explaining maximum proportion of own business willing to sell.

\begin{tabular}{|c|c|c|c|c|}
\hline \multicolumn{4}{|c|}{$\begin{array}{l}\text { Dependent variable: Maximum proportion } \\
\text { willing to sell }\end{array}$} & \multirow[b]{2}{*}{$(4)^{a}$} \\
\hline $\begin{array}{l}\text { Explanatory } \\
\text { Variable }\end{array}$ & $(1)^{\mathrm{a}}$ & $(2)^{\mathrm{a}}$ & $(3)^{a}$ & \\
\hline D7 & $\begin{array}{l}0.21 * * \\
(0.020)\end{array}$ & $\begin{array}{c}0.19 * * * \\
(0.00)\end{array}$ & $\begin{array}{c}0.27 * * * \\
(0.00)\end{array}$ & $\begin{array}{c}0.28 * * * \\
(0.00)\end{array}$ \\
\hline D8 & $\begin{array}{l}0.18^{* *} \\
(0.04)\end{array}$ & $\begin{array}{l}0.15^{*} \\
(0.07)\end{array}$ & $\begin{array}{c}0.04 \\
(0.60)\end{array}$ & $\begin{array}{l}-0.03 \\
(0.71)\end{array}$ \\
\hline D10_I & $\begin{array}{c}0.26^{* * * *} \\
(0.00)\end{array}$ & $\begin{array}{c}0.23 * * * \\
(0.00)\end{array}$ & & \\
\hline D10_III & & & $\begin{array}{l}0.18 * * \\
(0.03)\end{array}$ & \\
\hline D10_IV & & & & $\begin{array}{c}0.29 * * * \\
(0.00)\end{array}$ \\
\hline A3 & $\begin{array}{l}-0.02 \\
(0.84) \\
\end{array}$ & & & \\
\hline A6 & & $\begin{array}{l}0.13 * * \\
(0.04)\end{array}$ & $\begin{array}{c}0.25^{* * * *} \\
(0.00)\end{array}$ & $\begin{array}{c}0.25^{* * * *} \\
(0.00)\end{array}$ \\
\hline $\begin{array}{l}\text { Standard } \\
\text { Error of } \\
\text { estimate }\end{array}$ & 0.26 & 0.26 & 0.28 & 0.27 \\
\hline $\begin{array}{l}\text { Uncentered } \\
\text { R-squared }\end{array}$ & 0.55 & 0.55 & 0.56 & 0.60 \\
\hline $\begin{array}{l}\text { Degrees of } \\
\text { freedom }\end{array}$ & 66 & 66 & 66 & 66 \\
\hline
\end{tabular}

${ }^{\mathrm{a}} \mathrm{P}$-values in parenthesis below coefficient estimates; * means significant at $10 \%$; ** means significant at $5 \%$; and $* * *$ means significant at $1 \%$.

Legend to additional variables in Table 4. Please see legend o Table 3 for definition of other variables.

\begin{tabular}{|l|l|}
\hline Variable & Definition \\
\hline & $\begin{array}{l}\text { Please indicate whether or not the following } \\
\text { will deter you from taking on partners and /or } \\
\text { co-owners so as to raise capital to expand. YES } \\
=1 ; \text { NO =0. }\end{array}$ \\
\hline D10_I & Not being able to make decisions quickly \\
\hline 10D_III & $\begin{array}{l}\text { Having to share profits with partners and co- } \\
\text { owners }\end{array}$ \\
\hline D10_IV & $\begin{array}{l}\text { Having to deal with tax authorities and other } \\
\text { government bodies. }\end{array}$ \\
\hline A3 & $\begin{array}{l}\text { Generally speaking, would you say that most } \\
\text { people can be trusted or that you need to be } \\
\text { very careful in dealing with people. }\end{array}$ \\
\hline
\end{tabular}

The explanatory power of the variable capturing respondents who thought Ghanaian workers work hard when not supervised closely (D8) is not significant in regressions (3) and (4), but has p-values of 0.04 and 0.07 in regressions (1) and (2) respectively (suggesting they would sell a higher proportion).

\section{v. MANAGERIAL IMPLICATION OF THIS STUDY}

The findings provide some insight to variables that appear to explain decisions to expand proportions of their own businesses or family business. These variables relate to the values of the people, (trust), corporate governance (variable D10_I) and dealing with tax and other government authorities. That the indicator of trust is significant in our regressions suggests that respondents will behave so as to protect themselves against uncertain situations as Hofstede (2001) suggested.

To Stock exchange regulators, stock exchange operators, governments and donor agencies, we suggest that there is the need for a new perspective on how to strategize to get more companies in sub-Saharan Africa to access the capital markets. Efforts to increase stock market activities in sub-Saharan Africa have to go beyond identifying and removing transactional bottlenecks - trading systems, liquidity, institutions, efficiency, legal environment, market integration, etc.

Findings suggest that deliberate efforts aimed at understanding how the culture of the people and how the business environment influence entrepreneurs' decision to expand are important. It has been documented that Ghanaian entrepreneurs are wary of loss of control if they raise funds to expand their businesses by taking on additional owners, (Acquah, 2015). This study suggests that the fear of losing control has a basis. For example, hiring more workers as a result of expansion may mean not being able to supervise them closely. This inability may translate to relatively lower productivity per worker in the expanded business. Another issue about expansion that influences entrepreneurs is the situation whereby expansion translates to having to accept co-owners (shareholders) about whom entrepreneurs have reservations about the extent to which such can be trusted. (Many of such would have bought shares in the capital market and therefore be unknown to original entrepreneurs).

The findings also suggest that given an improved business environment Ghanaian entrepreneurs are likely to respond by being more willing to sell a higher proportion of their businesses to others to raise money on capital markets.

It will be instructive to expand this study to include more entrepreneurs and business owners in Ghana and to extend it to cover entrepreneurs and business owners in other sub-Saharan African countries that have fledgling capital markets, so that some African consensus can begin to emerge. Also, to be addressed at the next stage will be a broader understanding of other sociological and psychological issues that influence decision making by entrepreneurs and business persons.

\section{References}

[1] Aboagye, A.Q.Q, "The Impact of Financial Liberalisation and Capital Flows on Economic Output in Sub-Saharan Arica," in Internalisation and Enterprise Development in Ghana, Kuada, J. (Ed), Adonis \& Abbey, London, 2005, pp. 293318.

[2] Acemoglu, D, S. Johnson S and J. Robinson, Institutions as the Fundamental Cause of Long-run Growth, National Bureau of Economic Research, Working Paper 10481, 2004.

Adler, N. J, International Dimensions of Organizational Behavior, Ohio, South-Western Cincinnati, 1997.

[4] Acquaah, M, Managerial social capital, strategic orientation, and organizational performance in an 
Proc. of the Third Intl. Conf. on Advances in Management, Economics and Social Science - MES 2015.

Copyright (C) Institute of Research Engineers and Doctors, USA .All rights reserved.

ISBN: 978-1-63248-081-1 doi: 10.15224/ 978-1-63248-081-1-37

African emerging economy. Strateg. Manag. J. 28, 2007, pp. 1235-1255.

[5] Acquaah, M, Determinants of corporate listings on stock markets in Sub-Saharan Africa: Evidence from Ghana. Emerging Markets Review 22, 2015, pp. 154-175

[6] Agyeman, C. A, How the Ghana Stock Exchange (GSE) can be Improved, Unpublished B.Sc. Dissertation, Ashesi University, Ghana, 2010.

[7] Benimadhu, S, Challenges facing African capital markets. Presentation at UNECA Forum. Johannesburg, 2003. Retrieved May 2014 from http://www.uneca.org/eca_resources/major_eca_we bsites/CMD/workshop/Challenges\%20facing\%20A frican\%20Capital\%20Markets\%20-

UNECAOct2003.ppt

[8] Billmeier, A and I. Massa, What drives stock market development in emerging markets institutions, remittances, or natural resources? Emerg. Mark. Rev. 10, 2009, pp. 23-35.

[9] Corbetta, G., C. Salvato, Self-serving or selfactualizing? Models of man and agency costs in different types of family firms: a commentary on comparing the agency costs of family and nonfamily firms: conceptual issues and exploratory evidence. Enterp. Theory Pract. 28 (4), 2004, pp. 355-362.

[10] Davis, J. H, F. D. Schoorman and L. Donaldson, Toward a stewardship theory of management, Acad. Manag. Rev. 22 (1), 1997, pp. 20-47.

[11] El-Wassal, A. K, Understanding the growth in emerging stock markets. Journal of Emerging Market Finance, 4(3), 2005, pp. 227-261.

[12] Goldsmith, R.W, Financial Structure and Development, New Haven, Yale University Press, 1969.

[13] Gorodnichenko, Y and G. Roland, Which dimensions of culture matter for long run growth? American Economic Review, 101(3), 2011, pp. 492498

[14] Hearn, B, The liquidity cost implications arising from the attraction of regional primary listings: evidence from West Africa. Res. Int. Bus. Financ. 30 (1), 2014, pp. 91-110.

[15] Hearn, B. and J. Piesse, Barriers to the development of small stockmarkets: a case study of Swaziland and Mozambique. J. Int. Dev. 22, 2010a, pp. 1018-1037.

[16] Hearn, B. and J. Piesse, Modelling size and illiquidity in West African equity markets. Appl. Financ. Econ. 20 (13), 2010b, pp. 1011-1030.

[17] Hofstede, G. Culture's Consequences: Comparing Values, Behaviors, and Organizations Across Nations, Sage Publications, London, 2001.

[18] King R. G and R. Levine, Finance and growth: Schumpeter might be right. Quarterly Journal of Economics, 108, 1993, pp. 717 - 738.

[19] La Porta, R., F. Lopez-de-Silanes, A. Shleifer, anfd R. Vishny,. Legal determinants of external finance. J. Financ. 52 (3), 1997, pp. 1131-1150.
[20] La Porta, R., F. Lopez-de-Silanes, A. Shleifer, R. Vishny,. Law and finance. J. Polit. Econ. 106, 1998, pp. 1113-1155.

[21] La Porta, R., F. Lopez-de-Silanes, A. Shleifer, R. Vishny, Investor protection and corporate governance. J. Financ. Econ. 58, 2000, pp. 3-27.

[22] Lucas, R. E, On the Mechanics of Economic Development. Journal of Monetary Theory, 1988, pp. 22:.3-42.

[23] Marashdeh, H. A. and H-A. Al-Malkawi, Financial Deepening and Economic Growth in Saudi Arabia. Journal of Emerging Market Finance, 13(2), 2014, pp. 139-154.

[24] McKinnon, R. I, Money and Capital in Economic Development, Brookings Institution, Washington, DC, 1973

[25] North, D. C, Institutions, Institutional Change and Economic Performance. Cambridge University Press, Cambridge, 1990.

[26] Papamarcos, S. D. and G. W. Watson, Culture's Consequences for Economic Development: An Empirical Examination of Culture, Freedom, and National Market Performance. Journal of Global Business and Technology, 2(1), 2006, pp. 48-57.

[27] Schumpeter, J. A, The Theory of Economic Development Cambridge, Harvard University, Cambridge, 1912.

[28] Singh, A, Stock Markets, Financial Liberalisation and Economic Development', Economic Journal, 107(2), 1997, pp. 771-782.

[29] Stiglitz, R. E, Whither Socialism? MIT Press, Cambridge, 1994.

[30] Uyanga, J. and T. Suruga, Nexus between Financial Sector Development and Economic Growth: Empirical Analysis of 112 Countries. Journal of International Cooperation Studies, 5(3), 2008, pp. :95-116.

31] World Values Association, World Values Survey, 2012. Retrieved March 2014 from http://en.wikipedia.org/wiki/World_Values_Survey

[32] Yartey, C. and C Adjasi, Stock Market Development in Sub-Saharan Africa: Critical Issues and Challenges', IMF Working Paper, WP/07/209,2007. 